\title{
Predictions of Daily Horizontal Solar Radiation for Rural Development: The Case of Mubi Town, Adamawa State, Nigeria
}

\author{
${ }^{\mathrm{a} L .}$ Raji*, ${ }^{\mathrm{b}} \mathrm{R} . \mathrm{O}$. Amusat, ${ }^{\mathrm{C}} \mathrm{O}$. J. Anjorin, ${ }^{\mathrm{a}} \mathrm{M} . \mathrm{H}$. Idris, ${ }^{\mathrm{a}} \mathrm{A} . \mathrm{K}$. Issa \\ aDepartment of Mechanical EngineeringTechnology, Federal Polytechnic Mubi, Adamawa State \\ 650272, Nigeria \\ bepartment of Physics, University of Maiduguri, Maiduguri, Borno State, 1069 Bama, Nigeria \\ ¿Urban and Regional Planning, Federal Polytechnic, Mubi, Adamawa State 650272, Nigeria.
}

Received 6 January 2020; accepted 9 April 2020

\begin{abstract}
The solar radiation which is produced by the sun has created interests for the renewable researchers in the area of solar technology to make environment friendly and develop communities through this abundant energy potential. This study developed a model of Daily Horizontal Solar Radiation (DHSR) for Mubi, Adamawa State, Nigeria. The present study data were obtained from National Aeronautics and Space Administration (NASA) in year 2017. The sought data were air temperature and Relative Humidity which were used as the input parameters and DHSR used as output. Mathematical Model of DHSR of the study area was generated through the Multiple Linear Regression (MLR) analysis that was done in the Microsoft World Excel. Results of the research were validated using statistical tools of Mean Square Error and Correlation Coefficient given 1.61 and 0.95 respectively. Consequently, it was concluded that MLR Model can be considered as a substitute for evaluating the Actual DHSR for weather condition data of Mubi. Therefore, this finding is significant to the development of the socio-economic activities of the Mubi Town. Based on this finding it was recommended that the behavious of MLR Model should be tested in other locations across the Northeast, Nigeria.
\end{abstract}

\section{KEYWORDS}

Solar radiation Renewable energy rural Development relative Humidity

\section{INTRODUCTION}

The sun which radiates heat and light produces solar energy which is an important, clean, cheap, and abundantly available renewable energy. Solar energy is known as an ancient, clean source and it is the basic ingredient of almost all fossil and renewable energy on earth. This abundant source of energy is accessible in most places and its utilization is important, especially at the present time of continuous rise in the price of fossil fuels and the global warming which has become an issue that really concerns International Community (Khatib, Mohammed, \& Sopian, 2012). Thorough implementation of solar energy system policies across the world and particularly in Nigeria is faced with many obstacles; one of such obstacles is insufficient information on the key factors contributing to solar system technologies; one of such factors indude weather condition of particular location. 
RAJI, L. ET.AL

According to Najafi, Ghobadian, Mamat, \& Azmi (2015) renewable energy resources has potential for reducing the carbon dioxide $\left(\mathrm{CO}_{2}\right)$ emissions to the minimal levels, this makes it environmental friendly and a sustainable energy option around the globe. The studies have shown the relevance of solar radiation to energy production and supply the world over. Abundant energy potential from solar radiation play an important role in meeting the growing world energy demand (Akikur, Saidur, Ping, \& Ullah, 2013; Azoumah, Yamegueu, Ginies, Coulibaly \& Girard, 2011; Ming, De_Richter, Liu \& Caillol, 2014). Solar energy has attracted enormous attention not only because it is sustainable but also abundant and environmental friendly (Akikur et al., 2013; Hassan, Khalil, Kaseb, \& Kassem, 2017).

Al-sbou \& Alawasa (2017) studied solar radiation prediction in Mutah city, Jordan by collecting 2015 hourly weather data of temperature, wind speed and humidity used as input for prediction, the seven models of solar radiation produced using artificial neural networks (ANN). The statistical tools used to analyze the performance of models were MSE (2.73) and Regression (0.988) valve which revealed that model seven had good agreement with measured value of solar radiation.

Olatomiwa, Mekhilef, Shamshirband \& Petkovic (2015) presented potential of solar radiation prediction in Nigeria, using Support Vector Regression (SVR) to build model. Their model was based on measured meteorological data from Iseyin meteorological station in Nigeria. They concluded that SVR estimated better than Radial Basis Function (RBF) based on the coefficient of determination $\left(\mathrm{R}^{2}\right)$ values obtained.

According to Luqman, Shodiya, Ngala, Oumarou \& Mohammed (2016) Northeast in Nigeria is blessed with abundant renewable energy source which in solar and other renewable energy. but to finite reserves of fossil fuel adverse environment affects such as air pollution, depletion of ozone layer and global warming trigger the needs to promote renewable energy.

Consequently, Luqman et al. (2016) used linear regression in Micro Excel 2013 to predict Models of Global Solar Radiation in Maiduguri, Nigeria. The sunshine measured data in Maiduguri Borno State meteorological service in the periods between 1996 to 2010 were used. The Researcher tested models using standard deviation, variation and correlation coefficient statistical tools and it was revealed that logarithmic model had highest value of correlation coefficient (0.7928) with least value of deviation.

Also, Abdulazeez (2011) employed Feed Forward Back Propagation Neural Network for monthly estimation of average Global Solar Radiation (GSR) in Gusau, Nigeria. The input parameters were sunshine duration, maximum ambient temperature, relative humidity and solar radiation as output. The results showed good estimate between the predicted and measured values of global GSR with statistical analysis of regression, mean percentage error and root mean square error of $0.9996,0.8512$ and 0.0028 respectively.

The recent researches showed the favorable results on Multiple Regression (MR) and Artificial Neural Network (ANN) as applied in many engineering fields for prediction. The capability of MR and ANN to learn and at the same time generate equation among data sets gives them satisfactory for quick estimation and more attractive for many engineering applications. The multiple regression offers the ability to handle huge amount of data sets both in linear and complex nonlinear with ability to detect possible relation between dependent and independent variables. 
Based on the foregoing therefore, this study aims at developing a new regression model to predict the DHSR through minimum input parameters and use the model to predict the implications on community development.

\section{MATERIALS AND METHODS}

\section{Study Area}

Mubi town, which also doubles as the headquarter of Mubi North Local Government Area in Adamawa State, is located on Latitude $10^{\circ} 16 \mathrm{~N} \& 10^{\circ} 31^{\prime} \mathrm{N}$ and Longitude $13^{\circ} 16^{\prime} \mathrm{E} \& 13^{\circ} 32^{\prime} \mathrm{E}$. It is the $2^{\text {nd }}$ largest city and the commercial capital of the State. Mubi which located in the Northeastern part of Nigeria and lies within Sudan savannah, experiences annual rainfall between $900 \mathrm{~mm}$ and $1050 \mathrm{~mm}$ (NPC, 2006 in official Gazatte 71/52007/2500CoL24). The town (Mubi) is 580m a.b.s.l (NASA, 2018).

\section{Solar Resource and Weather Data}

Secondary data of climate/weather elements used are the Daily Horizontal Solar Radiation (DHSR $\left[\mathrm{kWh} / \mathrm{m}^{2} /\right.$ day $\left.]\right)$, the air temperature $\left(\mathrm{T}_{\mathrm{i}}\left[{ }^{\circ} \mathrm{C}\right]\right)$ and the relative humidity $\left(\mathrm{RH}_{\mathrm{i}}[\%]\right)$ of the study area as shown in Table 1. Were used for this study. These secondarily data were sourced from NASA. Other relevant non-climate data such as air temperature and the relative humidity were sourced from relevant literatures (either print or online). Data were collected and organized (Tabulated) on Monthly basis (January to December). This makes it possible to view the monthly occurrence and recordings of each of the three (3) climatic elements. Consequently, equation and model are easily generated through the process. To develop MR Model, the obtained data were sub-divided into two subsets as follows:

i. The air temperature and the relative humidity which served as the input variables.

ii. The DHSR which is the output variable.

Table 1. Experimental values of the Daily Horizontal Solar Radiation (DHSR [ $\mathrm{kWh} / \mathrm{m}^{2} /$ day $]$ ), the air temperature $\left(\mathrm{T}_{\mathrm{i}}\left[{ }^{\circ} \mathrm{C}\right]\right)$ and the relative humidity $\left(\mathrm{RH}_{\mathrm{i}}[\%]\right)$

\begin{tabular}{cccc}
\hline Mouths & $\mathrm{T}_{\mathrm{i}}\left({ }^{\circ} \mathrm{C}\right)$ & $\mathrm{RH}_{\mathrm{i}}(\%)$ & $\mathrm{DSRH}\left(\mathrm{kW} / \mathrm{m}^{2} / \mathrm{day}^{\circ}\right.$ \\
\hline January & 25.00 & 18.80 & 5.94 \\
February & 27.00 & 15.90 & 6.36 \\
March & 30.00 & 25.20 & 6.55 \\
April & 29.50 & 49.70 & 6.24 \\
May & 27.80 & 64.60 & 5.87 \\
June & 25.90 & 75.00 & 5.42 \\
July & 24.50 & 80.50 & 4.98 \\
August & 24.40 & 80.00 & 4.75 \\
September & 25.00 & 75.90 & 5.23 \\
October & 26.60 & 54.40 & 5.71 \\
November & 27.70 & 25.00 & 6.09 \\
December & 25.70 & 20.80 & 5.82 \\
\hline Annual & 26.00 & 49.00 & 5.74 \\
\hline
\end{tabular}


RAJI, L. ET.AL

Thereafter, the input variables were subjected to multiple regression in the Microsoft World Excel (2016) for the analysis. This software is known to be capable of adjusting the weight and minimizing the errors between the network output and the actual values. The Consequence of the adjustment of the data set in the software is the emergence of prediction equation.

Furthermore, to predict relationships between more than two (2) variables (dependents and independent) Mathematical Model of Multiple Linear Regression Equation was developed through MLR that was done in Microsoft world excel (2016). Hence, the general equation of MLR is as stated below:

$$
Y=p_{0}+p_{1} x_{1}+p_{2} x_{2}+\cdots+p_{k} x_{k}+\varepsilon \cdots
$$

Where: $Y$ is dependent variables,

$x_{k}$ is independent variables,

$p_{0}, p_{1}, p_{2}, \ldots, p_{k}$ are predicted variables,

$\varepsilon$ is the random error.

\section{Performance Validation of Model}

To validate the performance of the developed model, Mean Square Error (MSE) and Correlation Coefficient $\left(\mathrm{R}^{2}\right)$ tools were used for model performance validation. Below are the formulae for the tool.

(a) Mean square error. It is expressed as

$$
M S E=\sqrt{\frac{\sum_{i}^{n}\left(s_{p}-s_{o}\right)^{2}}{n}}
$$

(b) Correlation coefficient. It is expressed as

$$
M S E=\frac{\sum_{i}^{n}\left(s_{p}-\bar{s}_{p}\right)\left(s_{o}-\bar{s}_{o}\right)}{\sqrt{\sum_{i}^{n}\left(s_{p}-\bar{s}_{p}\right)^{2}} \sqrt{\sum_{i}^{n}\left(s_{o}-\bar{s}_{o}\right)^{2}}}
$$

Where, $s_{o}$ and $\bar{s}_{o}$ is actual value and average value of the Daily Horizontal Solar Radiation respectively.

$s_{p}$ and $\bar{s}_{p} \bar{s}_{o}$ is predicted value and average value of the Daily Horizontal Solar Radiation respectively.

\section{RESULTS AND DISCUSSION}

The main purpose of applying MLR Model is to assess the capability of the MLR in predicting the solar radiation of Mubi Town. The physical characterization of the DHSR has two inputs: Air Temperature and Relative Humidity were used as input and measured DHSR used as output. 
These parameters form the basis of the model, which is empirical in nature. Thus, an MLR Mathematical Model developed using the knowledge of the physical component of the weather condition data in the study area is as shown in the expression below.

$$
D H S R=1.7518+0.1730 T_{i}+0.0122 R H_{i}
$$

The predicted DHSR of the model (equation 4) and measured data values were compared in Table 2. Therefore, 1.61 and 0.95 were arrived at as MSE and $\mathrm{R}^{2}$ respectively. Consequently, this values are indicative of high predictive power of the model as a trend of low MSE and the value of $\mathrm{R}^{2}$ is approaching 1 (Julien, Emmanuel, Clément, Rufin, \& Brice, 2013).

Table 2. Experimental values of the actual DHSR and those predicted using MLR Model values

\begin{tabular}{ccc}
\hline Mouths & $\begin{array}{c}\text { Actual DHSR } \\
\left(\mathrm{kWh} / \mathrm{m}^{2} / \text { day }\right)\end{array}$ & $\begin{array}{c}\text { Predicted DHSR } \\
\left(\mathrm{kWh} / \mathrm{m}^{2} / \text { day }\right)\end{array}$ \\
\hline January & 5.94 & 5.85 \\
February & 6.36 & 6.23 \\
March & 6.55 & 6.63 \\
April & 6.24 & 6.25 \\
May & 5.87 & 6.77 \\
June & 5.42 & 5.31 \\
July & 4.98 & 5.00 \\
August & 4.75 & 4.99 \\
September & 5.23 & 5.15 \\
October & 5.71 & 5.69 \\
November & 6.09 & 6.24 \\
December & 5.82 & 5.94 \\
\hline Annual & 5.75 & 5.65 \\
\hline
\end{tabular}

\section{Implications of DHSR for Community development}

(a) Agriculture: Though Mubi is within the Sudan Savannah region, yet agriculture is one of the predominant occupations in the area. Some of the crops grown in Mubi include Maize, Millet and Groundnut. Also, there is large scale of animal rearing (Cattles goats or poultry) in Mubi. Hence, the knowledge of DHSR will help farmers, herders and other stake holders to apply appropriate procedures in their farm business. The return will surely be higher than expected.

(b) Power Generation (Electricity): Thomas \& Jose (2002) emphasized that the contribution of energy to community development is crucial. Every resident used electricity in one way or the other to satisfy their basic needs. The quantity of daily energy needs for every community is closely related to their level of development (poverty alleviation, population grouth and urbanization). United Nations Development Programme, UNDEP (2000) emphasized the significance of electricity to community (rural or urban) development to lightening and powering of homes appliances as well as sustenance of the continuous functionality of hospitals, factories and schools. Hence, predictability of the DSRH of any community, in general and Mubi to be specific, goes a long way to point at its level of development. This 
RAJI, L. ET.AL

reason is due to the possibility to generated energy from the solar radiation especially when found to be sufficient.

(c) Industrial Development: The level of industrial development of any region is a pointer to her level of economic growth. Such industrial development will transform a community from agrarian to industrial one, which will see to extensive re-organization of the economy of the community or region. Consequently, the DSRH of any community (or Mubi town) can help to raise the level of industrialization of the town. Agro-processing industries can spring up due to improvement in agricultural practice and output. Also, other non-agricultural based industries can as well be established due to the stability in power generation (from solar radiation) in the study area.

\section{CONCLUSION AND RECOMIMENDATION}

\section{Conclusion}

MLR model is a crucial tool not only in engineering for predicting the DHSR but in regional development for the prediction of specific areas of intervention that can lead to economicreorganization of any community (urban and rural). Therefore, prediction of DHSR of Mubi Town is a useful tool for engineering and socio-economic development of the town.

\section{Recommendation}

Based on the finding of this study in Mubi, Adamawa State, it is recommended that the DHSR predicting Model should be replication in various locations in the North Eastern part of Nigeria such as Maiduguri, Yola, Gombe etc. in order to boost the confident in the solar radiation model developed in the area (Nigeria).

\section{REFERENCES}

Abdulazeez, M.A., 2011. Artificial neural network estimation of global solar radiation using meteorological parameters in Gusau, Nigeriaa. Archives of Applied Science Research 3(2), 586595.

Akikur, R.K., Saidur, R., Ping, H.W., Ullah, K.R., 2013. Comparative study of stand-alone and hybrid solar energy systems suitable for off-grid rural electrification: A review. Renewable and Sustainable Energy Reviews 27, 738-752.

Al-sbou, A.Y., Alawasa, M.K., 2017. Non-linear auto regressive recurrent neural network model for solar radiation prediction. International Journal of Applied Engineering Research 12(14), 45184527.

Azoumah, Y., Yamegueu, D., Ginies, P., Coulibaly, Y., Girard, P., 2011. Sustainable electricity generation for rural and peri-urban populations of sub-Saharan Africa: The "flexy-energy" concept. Energy Policy 39(1), 131-141. https://doi.org/10.1016/j.enpol.2010.09.021

Hassan, A.M., Khalil, A., Kaseb, S., Kassem, M.A., 2017. Potential of four different machine-learing algorithms in modeling daily global solar radiation. Renewable Energ, 108(17).

Julien, G.A., Emmanuel, L., Clément, A., Rufin, O. A., Brice, A.S., 2013. Modeling solar energy transfer through roof material in Africa sub-saharan region. Renewable Energy, 34(7), 632-645.

Khatib, T., Mohammed, A., Sopian, K., (2012). A review of solar energy modelling techniques. 
Renewable and Sustainable Energy Reviews, 16(5), 2864-2869.

Luqman, R., Shodiya, S., Ngala, G.M., Oumarou, M.B., Mohammed, A. B., 2016. Pre-assessement models of global solar radiation using sunshine duration in Maiduguri. ATBU,Journal of Science, Technology \& Education 4(1), 174-178.

Ming, T., De_Richter, R., Liu, W., Caillol, S., 2014. Fighting global warming by climate engineering: Is the Earth radiation management and the solar radiation management any option for fighting climate change? Renewable and Sustainable Energy Reviews, 31, 792-834. https://doi.org/10.1016/j.rser.2013.12.032

Najafi, G. B., Ghobadian, R., Mamat, T. Y., Azmi, W., 2015. Solar energy in Iran: Current state and outlook. Renewable and Sustainable Energy Reviews, 49, 931-942. https://doi.org/10.1016/jrser.2015.04.056

NASA. 2018. Atmospheric Science Data Centre. Retrieved from https://eosweb.larc.nasa.gov

Olatomiwa, L., Mekhilef, S., Shamshirband, S., Petkovic, D., 2015. potential of support vector regression for solar radiation prediction in Nigeria. Nat Hazards, 77, 1055-1068.

Thomas, B.J., \& Jose, G., 2002. Energy for sustainable development: A policy agenda. United Nation Development programm. Bureau for development policy.New York, NY 10017.USA.

UNDEP.2000. United Nation Development Programme (UNDP), United Nations Development of Economic and Social Affairs (UNDESA), 1951, World Energy Council (WEC),2000. World Energy Assessment. Energy and the Challenge of Sustainability. World Energy Assessment. Energy and the Challenge of Sustainability. 